\title{
A Literary History of the Mandarin Orange in Canada
}

\section{[Place Figure 1.0 about here]}

When grappling with history, we debate what constitutes turning points, such as major events or larger societal transformations. In literature, readers also identify turning points, or plot developments, which alter a character's situation or fortune. But what constitutes a turning-point food? Canadian literature provides some answers of the transformative aspects of foodways through the example of Japanese oranges. First imported to Canada (and particularly the western provinces of British Columbia, Alberta, Saskatchewan, and Manitoba) in the late 1800s, this popular wintertime fruit regularly appears in the nation's literature symbolizing the potential for other worlds of experience when faced with frigid or dreary environments. For Canadian writers, the fruit's exotic origins, material qualities (vibrant color, globe-like shape, etc.), and seasonal traditions have provided abundant food for thought when expressing transformative experiences or a yearning for them.

\section{Peeling Back the Canadian History of a Japanese Import}

During late fall, boxes of Mandarin oranges become widely available in Canadian grocery stores in anticipation of the holiday season. Fall ends. Winter takes hold. And these cheery imports beckon to shoppers who long to brighten cold, grey days. Mandarin oranges, also known in Western Canada as Japanese oranges, were first introduced to Canada in the late 1800 s by way of Japanese immigrants. The Oppenheimer Group, a produce and provision company based in British Columbia 
since 1858, first imported the fruit in 1891 to provide Japanese workers with a taste of their original home.("Company History" n.d.) [Place Figures 1.1-1.2 about here] Gift baskets were initially sent to Japanese immigrants by family members as a way to celebrate the New Year ("Fresh Story: Mandarin Oranges" 2018). The interchangeable use of the terms 'Japanese' and 'Mandarin' may cause some confusion, especially since Mandarin is a Chinese language. But there are many varieties of Mandarins (citrus reticulata) grown across the world and imported to Canada, including those shipped from Japan. According to the Oxford English Dictionary, the Anglicized name for the fruit stems from the Swedish term mandarin apelsin (Chinese orange) and was likely inspired by a "comparison of the fruit's colour with the yellow silk robes of mandarins"("Mandarin, n.2" 2018). The Portuguese were the first to apply this term to individuals "of the senior grades of the former imperial Chinese civil service"("Mandarin, n.1" 2018). The fact that the Mandarin words for 'gold' and 'orange' rhyme may also help to explain why oranges are a symbol of "wealth and good fortune in Chinese culture," the fruit "shared generously with friends and family during Chinese New Year" ("Fresh Story: Mandarin Oranges" 2018).

Once a taste for Mandarin oranges was established in Canada, there was no turning back. Consumers cherished this delectable fruit, which quickly became a popular, annual import. Indeed, the orange's festive associations are uniquely Canadian because many American states have long restricted the importing of citrus. Shipped across the Pacific Ocean to the Port of Vancouver in the early 1900s, crates of Japanese oranges used to travel across Western Canada on 'Orange Trains' 
- "boxcars painted orange to herald their arrival" (Proctor 2015). [Place Figure 1.3about here] The tradition of holiday oranges is evidently well established by the time Gabrielle Roy's novel The Tin Flute is published in 1945. Set in Montreal at the beginning of the Second World War, the story includes a hospital scene in which a young boy, Daniel, instantly recognizes the custom when he receives an out-ofseason orange: “But an orange wasn’t juice, it was a fruit you got at Christmas time. You found it in your sock on Christmas morning, and you ate it, quarter by quarter, making it last.... Funny that this Christmas fruit was now his! ... It wasn't winter and it wasn't Christmas, and there he was with a fine orange in his hand, round and soft and full."(Roy 1989) Sadly, Daniel is too ill to enjoy his orange, letting it fall to the side of his hospital bed. Certainly in Canadian literature, the rarity of Christmas oranges often draws attention to the daily hardships endured throughout the rest of the year. In her autobiography Half-breed, for example, Métis author Maria Campbell recalls her people's impoverished existence living on road allowances in

Saskatchewan. After spending months away from home trapping in order to provide for the family, Campbell's father would return on Christmas Eve as his own version of Santa Claus with "a sack full of fur on his back" (M. Campbell 1973, 54). On Christmas morning, the children's stockings would be "plumb full and overflowing with nuts and candy canes, oranges and apples—the only ones we ate all year," Campbell adds upon reflection.

Today, a variety of easy-to-peel Mandarins (tangerines, clementines, satsumas, pixies, etc.) are readily available throughout the year in grocery stores across Canada. But the larger boxes of Japanese oranges, often with each orange 
wrapped in paper, always appear around the holidays, sustaining this Western Canadian tradition (Akhtar 2018). Indeed, at the turn of the twenty-first century, "more than 99.5 per cent of mandarins shipped to Canada [were] sold in the four western provinces" with Western Canada being "Japan's largest overseas ... market" (Simons 2000). The Oppenheimer Group identifies this most expensive Mandarin as “'the Cadillac' of brands" with its "balance between sweet and tart"(Proctor 2015).

\section{Glowing Globes - Canadian Literary Mandarins}

Just as the Mandarin orange first enchanted late nineteenth-century Canadian consumers as a seasonal novelty, the fruit also inspired writers as a symbol of other worlds. One of the earliest Canadian poems in which this wintertime fruit assumes a central symbolic role is Louise Morey Bowman's “Oranges," which appears in her second book of poetry, Dream Tapestries (1924), for which she was awarded the Prix David in Quebec (W. Campbell n.d.). A Modernist poet, Bowman (1882-1944) captures the transformative effects of this citrus treat as she describes an austere, seemingly lifeless New England village during the colorless month of November. Tracing Bowman's career, Wanda Campbell notes that the New England setting featured in "Oranges" can be readily explained by a series of factors: Bowman originally submitted her poem to a contest in the United States; she had once studied in Massachusetts; and her grandmother was a Puritan (W. Campbell 2005, 82). While these American influences are clear, Campbell adds that the circumstances depicted in "Oranges" could easily "[resemble] turn-of-the-century Canada" with its restraining social mores and rigid piety (W. Campbell 2005, 82). In 
terms of turning points, Bowman's poem reflects shifting social norms and attitudes in a modernizing world; the oranges are central to expressing these changes.

In "Oranges," the New England townspeople faithfully sing hymns about mortality. Meanwhile, Death itself seems to occupy the town's stark streets and porches. All is staid and lackluster until the village store beckons with its "different air" - a kind of sensual music brimming with life and scents "from wild rich worlds beyond" (Bowman 2015, lines 46,51).

The storekeeper is "a man of vision and breadth of mind"(Bowman 2015, line 96). His wares include great works of literature, coffee beans, spices, cones of sugar, coarse salts, fabrics, and oranges:

Great balls of golden wonder ... round, perishable globes ...

Here a ripe pyramid most carefully laid $[\ldots]$

See how the oranges have caught up all the light! What joyous tones they hold Of vivid, bold, Hot colour!

They glow like balls moulded of molten gold. (Bowman 2015, lines 113-123) More than warding off winter, the vibrant orange pyramid offers the conservative community a sense of other realms. The burning "tones" create a change in both hue and timbre as the villagers' morose hymns and Sunday church bell give way to a new synesthetic experience. Indeed, the storekeeper's bell, placed above his door, 
chimes continually throughout the week marking customers' desire for the world, for those orange, "perishable globes." [Place Figure 1.4 about here.]

In the late 1800 s and early 1900s, Mandarin oranges were undeniably transformative, a turning point for Bowman's villagers. These memorable first impressions clearly left their mark on the nation's literary foodscapes. The famous prairie writer Sinclair Ross, for instance, uses Mandarin oranges to shape his smalltown Saskatchewan settings. In his 1939 short story “Cornet at Night,” a young farm boy named Tom feels intimidated and out of place during his first solo trip into town. This experience of independence within the wider world is clearly indicated when he enters a Chinese restaurant: its "pyramid of oranges in the window and the dark green rubber plant with tropical looking leaves ... and the dusky smell of last night's cigarettes," signaling “the orient itself."(Ross 1988, 38) Later, when Tom travels back home with Philip, a musician whom he meets at the Chinese restaurant and hires to help with the harvest (instead of the strong farmhand Tom's father had requested), a single note from Philip's cornet -- "gleaming in the August sun like pure and mellow gold" -- upsets the horse and cart and causes all of Tom's groceries - including oranges - to fall to the ground, the precious fruit disappearing down a badger hole (Ross 1988, 40). Just as Bowman's poem associates oranges with life's sensual 'music,' Ross uses the citrus to foreshadow the story's conclusion: the musician's quick departure after failing to stook the wheat. Young Tom is left with the memory of Philip's one impromptu performance in the family's bunkhouse, the music, like those lost precious oranges, transcending his prosaic prairie life: "A 
harvest, however lean, is certain every year; but a cornet at night is golden only once" (Ross 1988, 45).

Oranges carry an abundance of meaning for Ross as the fruit also assumes a prominent role in his 1942 novel As For Me and My House, which documents a couple's barren marriage during the dustbowl of the Great Depression. With Christmas being "a bleak season in a childless home," the protagonist, Mrs. Bentley, tries to make her domestic life more festive (Ross [1957] 1989, 195). But in a diary entry dated December $24^{\text {th }}$, she admits that holiday treats fail to bridge the emotional distance between her and her husband: "I polished a bowl of apples and set out another of oranges; and then called Philip for coffee and Christmas cake. But it wasn't very successful—our appetites and spirits keep abreast. It's easier when I take the coffee in to him, and then come away and let him have it by himself" (Ross [1957] 1989, 195). Later, during a frigid day in February, Mrs. Bentley draws upon the orange's other meanings, such as those traced by food writer Clarissa Hyman in her global history of the fruit. Hyman notes that artists have long associated the orange with fertility, "bare bosoms and zesty enticement," such as Botticelli's Venus, who "surf[s] modestly on a scallop shell to a shore lined with orange trees"(Hyman 2013, 98). Setting a similar kind of erotic symbolism in motion, Mrs. Bentley stuffs an old grain sack with oranges and hay (to insulate the fruit) and, sending the parcel with her husband to give to Judith, the pregnant woman with whom Mrs. Bentley suspects Philip is having an affair. When Philip returns, it's clear that Mrs. Bentley's underhanded 'gift' has had the desired effect: 
"And Judith?" I asked at last, pouring myself out another cup of tea to drink with him. "How was she? Did she send a message?"

It seemed as he looked up at me that something in his eyes broke. "Next time," he said, "you'd better not send the oranges." ... "She cried when I told her they were from you - all afternoon, one in each hand, as if that could help."(Ross [1957] 1989, 201)

In a lyric set twenty years later than Ross's short story and novel, in the urban environs of Montreal's Old Port during the 1960s, Mandarin oranges continue to make a sensual impression when savoring tea served with this fruit that has been shipped all the way from China. Here, you listen to the magical voice of Leonard Cohen in his famous song "Suzanne" and see his muse, Suzanne Verdal, dancing along the St. Lawrence River. While Cohen claims that Verdal "fed [him] a tea called Constant Comment, which has small pieces of orange rind in it, which gave birth to the image," Verdal remembers their encounter differently: "We had tea together many times and mandarin oranges ... I would always light a candle and serve tea and it would be quiet for several minutes, then we would speak. And I would speak about life and poetry and we'd share ideas"(Martyris 2016). Sylvia Simmons' biography of Cohen merges the two versions. Verdal here recalls having sourced "jasmine tea or Constant Comment and little mandarin oranges and lychee nuts from Chinatown," this a short distance from the Old Port (Simmons 2013, 126). This last detail gives added dimension to Cohen's description of the journey undertaken by the little fruit: "all the way from ..." is at once nearby Montreal Chinatown and faraway China. [Place Figure 1.5 about here.] Cindy Bigelow-the current CEO of 
the America's Bigelow Tea Company, which has produced Constant Comment since 1945 - naturally believes Cohen's version of events. And, as for the Mandarin oranges, one cannot help but sense Cohen's grounding in Canadian foodways and the long tradition of oranges infusing a note of exoticism into the Canadian culinary palette. Of course, Cohen's music and celebrity have since touched these oranges with their own kind of enchantment. Following Cohen's death in 2016, mourners living on the Greek island of Hydra have been leaving oranges, tea bags, and messages of remembrance on the doorstep of Cohen's one-time home (Vassilopoulos 2016).

But can a Mandarin orange become too much of a good thing? At the close of the twentieth century, Hiromi Goto's Chorus of Mushrooms asks us to think further about the fruit's multiple personalities. In Goto's novel, teenage Muriel eats an entire box of Mandarin oranges and lies down, satiated, under the Christmas tree. "I was replete," says Muriel. "I looked it up in the dictionary and that's exactly how I felt"(Goto 1994, 91). But her initial satisfaction, as we will see, is short lived. "If you eat too many oranges" Keiko and daughter Muriel discover, "your skin turns yellow" (Goto 1994, 91). Yellow skin for Muriel is as entertaining as having "red shit from eating too many beets."(Goto 1994,92$)$ It is something to be marvelled at, laughed at, and shared. Muriel shares this phenomenon with her mother: "Look Mom! . . Lookit my hands" (Goto 1994, 92). Keiko tries desperately to remove the yellow stains on her daughter's arms with an SOS pad, muttering, "Yellow, she's turning yellow she'sturningyellow she's-"(Goto 1994, 92). For Keiko, the orangeinduced stains are the site of an explicit racial qualification. 
Ever the wordsmith, Muriel enjoys her snack while critically considering the name of the fruit and its authenticity: “Jap oranges - funny how they're called Jap oranges." She muses, "When they are technically called Mandarin oranges and Mandarin isn't even a place but a Chinese Language. Funny how words and meaning twist beyond the dimensions of logic"(Goto 1994, 91). For Muriel, her snack is a delicious social construct. The effects of eating so many oranges (yellow skin) are the result of too much carotene in her system. For Keiko, who does not separate Jap from orange, this snack reveals the eater's inherent, essential difference. It is significant that this 'inherent, essential difference' as perceived by Keiko, is also a temporary physical condition. Muriel's carotene levels will eventually subside.

During frigid winters, Canadians' love of Mandarins is understandable. Who can resist that glowing fruit when the world around you is covered in snow and ice? And as for the particular Christmas tradition of Japanese oranges, journalist and senator Paula Simons notes that the fruit is "a modest testament to Western Canada's multicultural heritage ... Today, they are as much as part of our shared culture as perogies and butter tarts" (Simons 2000). As for Canadian writers, the fruit has become much more than a symbol of the winter holidays. Oranges communicate a range of desires: for passion, fertility, identity, and other worlds of sensorial and cultural experience, as well as for the taste of home for Japanese immigrants to Canada. The next time you purchase a box of Mandarin oranges at a Canadian grocery store, relish them one segment at a time. These lyrical oranges are bound to delight. 


\section{Bibliography}

Akhtar, Khalil. 2018. "Orange You Glad You Can Get Mandarins Year-Round?" CBC. December 6, 2018. https://www.cbc.ca/news/canada/orange-you-glad-youcan-get-mandarins-year-round-1.4935682.

Bowman, Louise Morey. 2015. “Oranges.” Canadian Poetry. November 22, 2015. http://www.canadianpoetry.ca/hidden_rooms/louise_morey_bowman.htm\& gt;

Campbell, Maria. 1973. Half-Breed. Toronto: Goodread Biographies.

Campbell, Wanda. 2005. "Moonlight and Morning: Women's Early Contribution to Canadian Modernism." In The Canadian Modernists Meet, edited by Dean Irvine, 79-99. Ottawa: University of Ottawa Press.

——_. n.d. "Louise Morey Bowman." Canadian Poetry. Accessed December 19, 2018.

http://www.canadianpoetry.ca/hidden_rooms/louise_morey_bowman.htm.

“Company History." n.d. Oppy. Accessed December 19, 2018. https://oppy.com/who-we-are/company-history.

"Fresh Story: Mandarin Oranges." 2018. BC Agriculture in the Classroom Foundation. February 2018. https://www.bcaitc.ca/sites/default/files/resources/Intermediate\%20Man darin\%200ranges\%202018.pdf.

Goto, Hiromi. 1994. Chorus of Mushrooms. Edmonton: NeWest Press.

Hyman, Clarissa. 2013. Oranges: A Global History. The Edible Series. London, UK: Reaktion Books.

“Mandarin, n.1." 2018. In OED Online. Oxford University Press. http://www.oed.com/view/Entry/113292.

“Mandarin, n.2." 2018. In OED Online. Oxford University Press. http://www.oed.com/view/Entry/113293.

Martyris, Nina. 2016. “The Story Behind the 'Tea and Oranges' in Leonard Cohen's Song 'Suzanne.'” NPR. November 15, 2016. https://www.npr.org/sections/thesalt/2016/11/15/502047665/the-storybehind-the-tea-and-oranges-in-leonard-cohens-song-suzanne.

Proctor, Jason. 2015. "Mandarin Idol: Which Orange Is Worthy of Citrus Stardom?” CBC. December 1, 2015. https://www.cbc.ca/news/canada/britishcolumbia/mandarin-idol-which-orange-is-worthy-of-citrus-stardom1.3344421.

Ross, Sinclair. 1988. “Cornet at Night.” In The Lamp at Noon and Other Stories, 29-50. New Canadian Library. Toronto: McClelland \& Stewart.

_-_. (1957) 1989. As For Me and My House. New Canadian Library. Toronto: McClelland \& Stewart.

Roy, Gabrielle. 1989. The Tin Flute. Translated by Alan Brown. New Canadian Library. Toronto: McClelland \& Stewart.

Simmons, Sylvia. 2013. The Life of Leonard Cohen. Toronto: McClelland \& Stewart.

Simons, Paula. 2000. "Mandarin Oranges a Prairie Tradition." Kingston Whig Standard, December 1, 2000. 
Vassilopoulos, Will. 2016. “Greek Islanders Pay Homage to 'Lovely Leonardos' Cohen.” Daily Magazine. 2016. http://www.dailymagazine.news/greekislanders-pay-homage-to-lovely-leonardos-cohen-nid-323327.html. 


\section{Image Captions}

\section{Figure 1.0:}

Oranges and Mandarin Oranges at Table. Photograph by Alexia Moyer.

\section{Figure 1.1:}

Christmas mandarin oranges being unloaded from the ship, SS American Mail, Vancouver, December 7, 1949. Photograph by Artray. Courtesy of Vancouver Public Library, Accession Number 81110.

\section{Figure 1.2:}

Christmas mandarin oranges being unloaded from the ship, SS American Mail, Vancouver, December 7, 1949. Photograph by Artray. Courtesy of Vancouver Public Library, Accession Number 81110A.

\section{Figure 1.3:}

Japanese orange crate. Courtesy of the North Vancouver Museum and Archives.

\section{Figure 1.4:}

Ladies at tea, oranges \& cookies, circa 1900, Eastern Townships, Quebec. Photograph by Sally Eliza Wood. Courtesy of the McCord Museum, MP-1994.32.6: "The oranges sold in Quebec probably came from Florida or California, two American states already famous for their orange groves. In 1900, oranges were an expensive commodity that only 
a wealthy few could afford to buy regularly. Most people only had them at Christmas or other special occasions."

\section{Figure 1.5:}

"she feeds you tea and oranges that come all the way from China." Photograph by Alexia Moyer. 


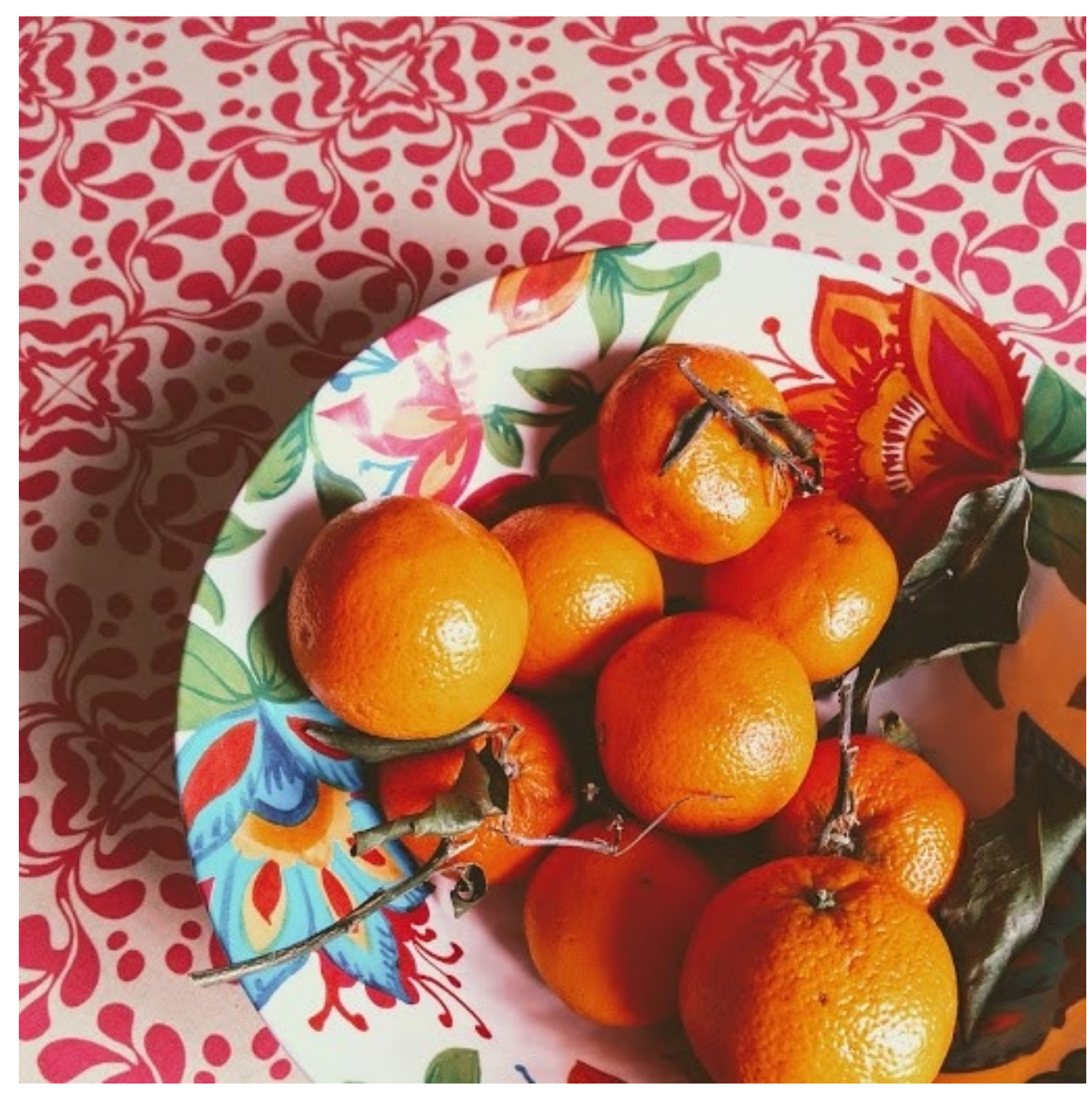

$135 \times 135 \mathrm{~mm}(96 \times 96 \mathrm{DPI})$ 


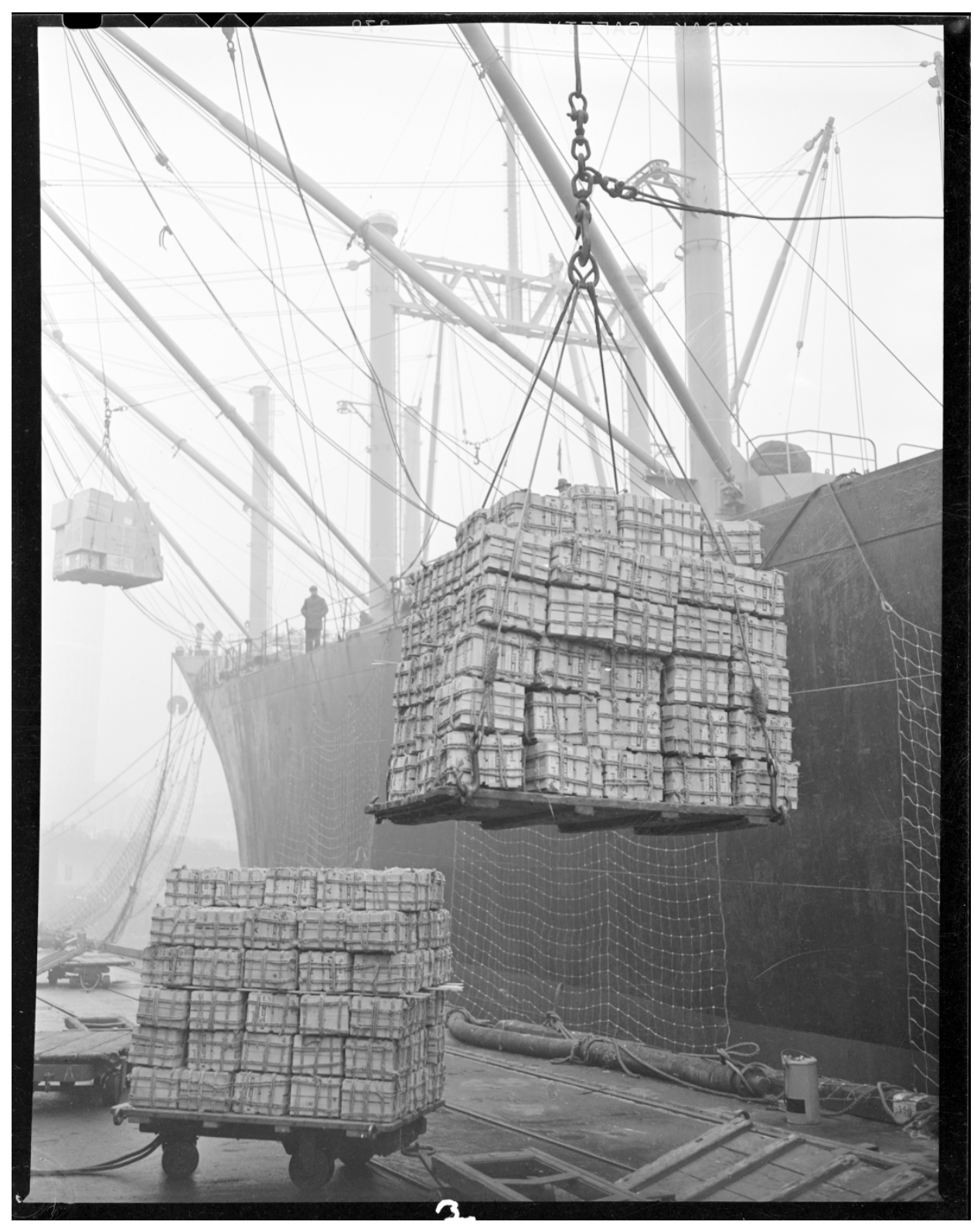




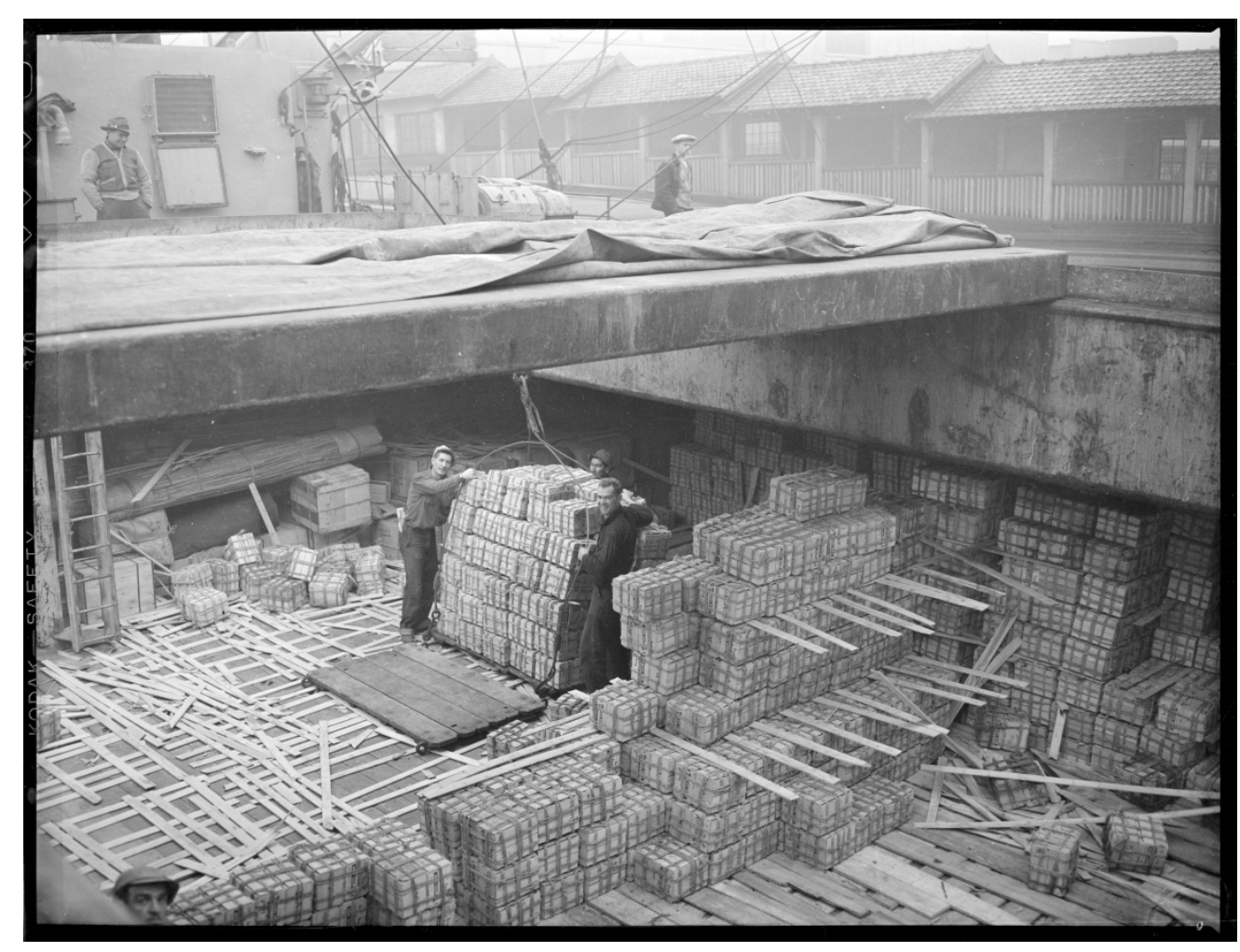




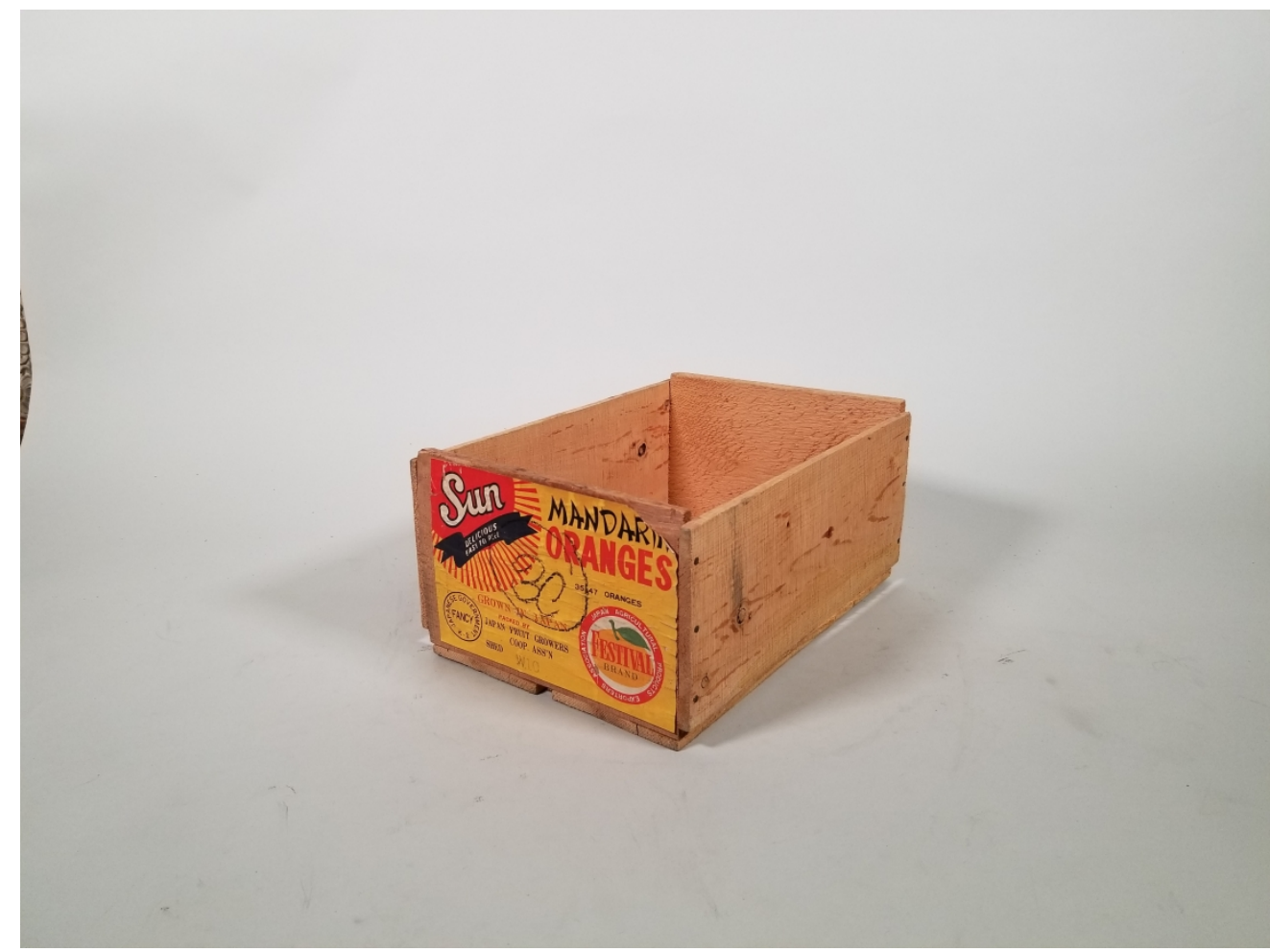

$1422 \times 1066 \mathrm{~mm}(72 \times 72 \mathrm{DPI})$ 


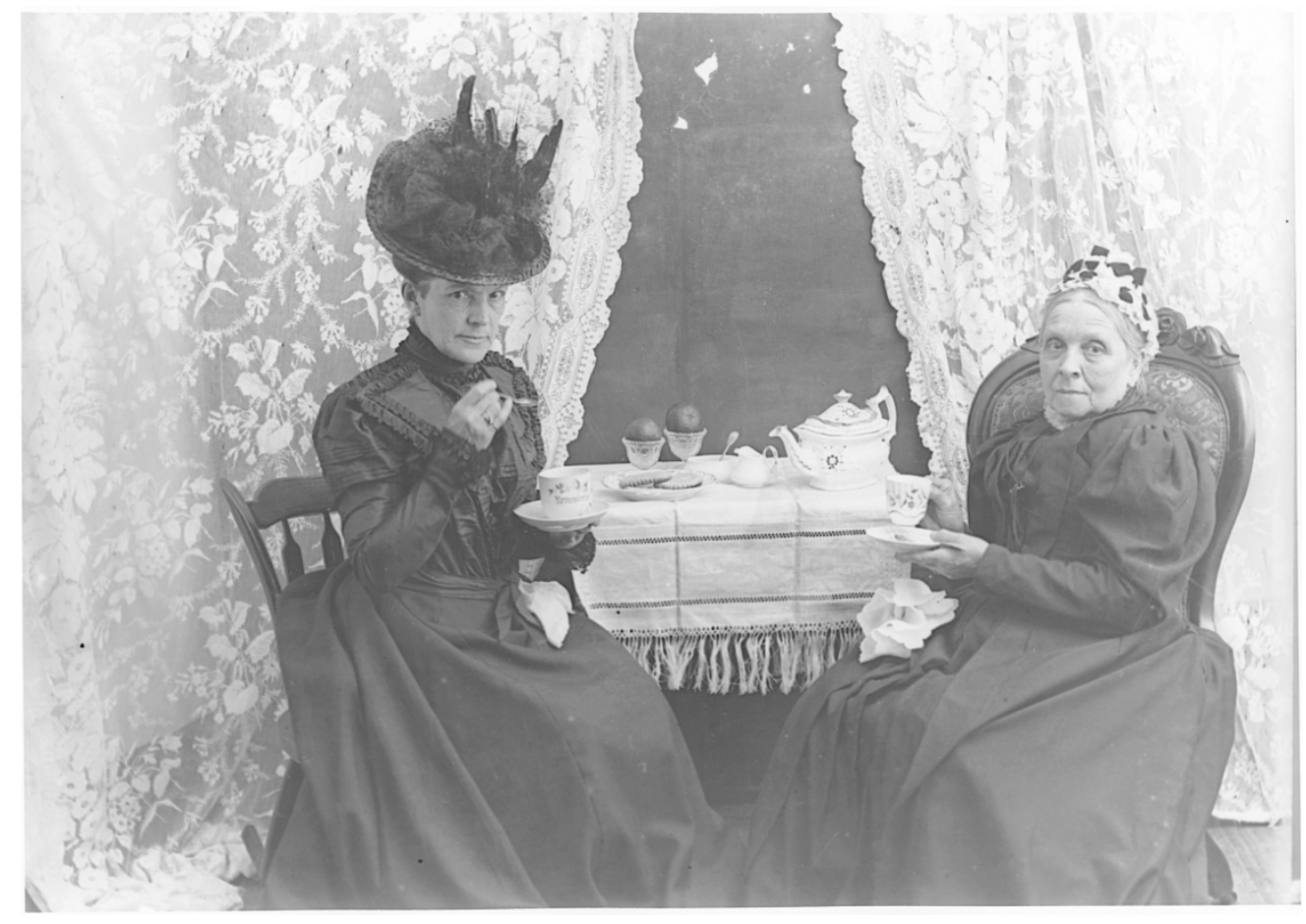




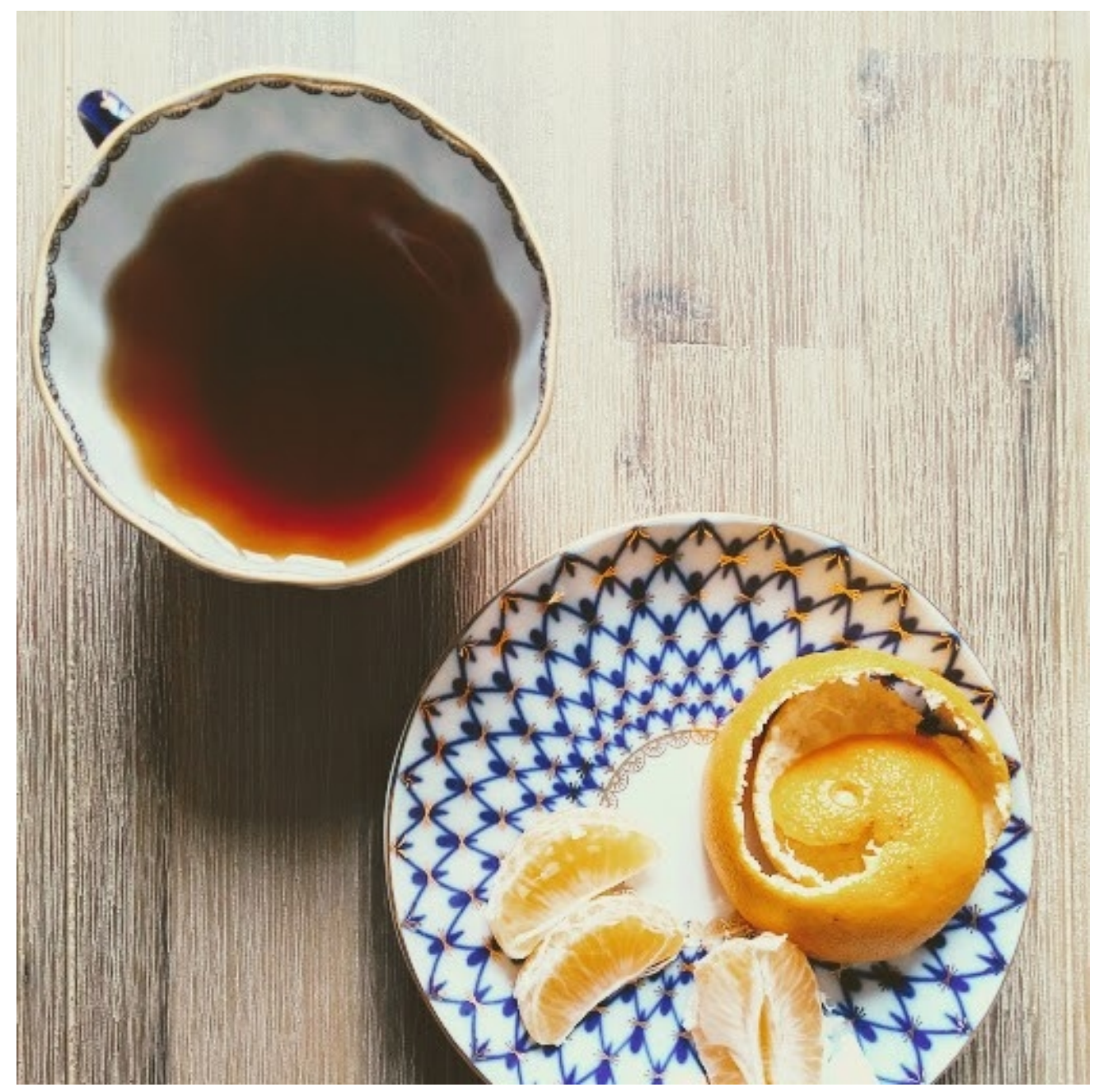

$135 \times 135 \mathrm{~mm}(96 \times 96 \mathrm{DPI})$ 